American Journal of Economics and Business Administration 2 (1): 39-44, 2010

ISSN 1945-5488

(C) 2010 Science Publications

\title{
Interaction of Export Instability and Openness-Growth Nexus In East Asia and Pacific Countries (1990-2006)
}

\author{
${ }^{1}$ Zamanian Gholamreza, ${ }^{2}$ Pourshahabi Farshid and ${ }^{2}$ Shirazi Ali \\ ${ }^{1}$ Department of Economics, Esfahan University, Esfahan, Iran \\ ${ }^{2}$ Department of Economics, Sistan and Baluchestan University, Zahedan, Iran
}

\begin{abstract}
Problem statement: Because of the importance of the relation between instability of economic variables and making decision for determinants, this is so considerable to find the interaction between instability and economic variables' activity. Approach: One of the efficacious factors to have a positive trade balance is export that is a factor of GNP growth too. Moreover, openness is an important factor for stimulus export. Results: For above reasons and to survey that what's the relation of these factors, in this study we try to investigate the effect of Investment and export instability on growth of 22 East Asia and Pacific countries that is a new subject of done articles. We apply panel data method because this method allows us to use more countries in a shorter period of time series data. Using data span is from 1990-2006 (WDI 2008). The result showed that a co-integration relationship between growth and its determinants is supported in the model. The results of panel Random Effect model that is estimated by using data show that: (1) There is a negative relationship between growth and export instability of this set of countries, (2) According to the studied investigation, coefficient of export is about 0.5 that mean the factor of export has greater effect on growth in these countries rather than other factors, (3) The impact of gross fixed capital and labor force is positive on growth in this set of countries. Conclusion/Recommendations: The results of study recommend that the policy of export stability must be to attend in decision of policy makers in these countries.
\end{abstract}

Key words: Export, instability, growth, East Asia and pacific countries

\section{INTRODUCTION}

The macroeconomic relationship between export and economic growth has been one of the most widely investigated in development literature. Therefore the effect of export instability on economic growth can be an important issue in discussion about export-growth nexus. Most studies that examine the relationship between export and economic growth indicate that it is export activity that leads to economic growth.

Base on Giles and Williams (2000); Kugler (1991) and Yaghmaian (1994) studies we can say that export expansion causes economic growth via the foreign trade multiplier. Export growth can foster specialization in exporter sectors, which have higher productivity levels. This application may leads to reallocation resources from inefficient sectors to exporter sectors. Therefore, the reallocation of resources in benefit of efficiency sector can lead to economic growth. Also, export can expand market size; give rise to substantial scale economics, haste capital formation and technology.

Simply the year to year fluctuation in exports figure is defined as export instability. The export instability of any country may create economic instability of the same country as well as other countries of the world because this world has been synchronizing by the process of globalization. In this regard, it is needed to give much attention to the effects of export instability on economic growth.

The explanation suggested for the relationship between export instability and industrialization that developing countries may be expected to play a role of residual suppliers of growth products on world markets due to their late entry into the world markets for growth products; their distance from consumers, which makes it difficult for them to follow the evolution of the tastes and needs of consumers; their limited spending on research and on product development; the differentiation inherent in growth products that makes the loyalty of consumers to products manufactured by early entrants into the markets a major obstacle for the new entrants; the difficulties that developing countries have in maintaining a production flow of even quantity and quality because of foreign exchange shortages to pay for imported inputs; the lack of standardization and

Corresponding Author: Pourshahabi Farshid, Department of Economics, Sistan and Baluchestan University, Zahedan, Iran 
the sophistication of the technology used in the manufacture of growth products and the oligopolistic nature of the markets for growth products, among other factors (Mullor-Sebastian, 1990).

Over time, the instability of growth products exported by developing countries can be expected to decline because the products mature and because the countries learn to produce and market the goods. Thus, if diversification into growth products has the advantage of introducing new technology and of broadening the industrial base of developing countries, the fact that export instability increases after diversification should not be a deterrent to exporting additional growth products (Mullor-Sebastian, 1990).

This study is concerned with the long run relationship between interaction of export instability and trade openness in the growth of East Asia and Pacific countries. We used panel co-integration method to determine the long run equation.

Literature review: Nothing matters more to the longterm economic welfare of a nation than its rate of economic growth. Compounded over many years, seemingly small differences in annual growth rates can lead to vast differences in standards of living. Research on economic growth has exploded in the past decade. Hundreds of empirical studies on economic growth across countries have highlighted the correlation between growth and a variety of variables.

Despite the lack of a unifying theory, there are several partial theories that discuss the role of various factors in determining economic growth. Two main strands can be distinguished: The neoclassical, based on Solow's growth model, has emphasized the importance of investment and, the more recent; theory of endogenous growth developed by Romer (1986) and Lucas (1988) has drawn attention to human capital and innovation capacity. Furthermore, important contributions on economic growth have been provided by Myrdal's cumulative causation theory and by the New Economic Geography School. In addition, other explanations have highlighted the significant role noneconomic (in the conventional sense) factors play on economic performance. These developments gave rise to a discussion that distinguishes between 'proximate' and 'fundamental' (or 'ultimate') sources of growth. The former refers to issues such as accumulation of capital; labor and technology while the latter to institutions, legal and political systems, socio-cultural factors, demography and geography. Investment is the most fundamental determinant of economic growth identified by both neoclassical and endogenous growth models. However, in the neoclassical model investment has impact on the transitional period, while the endogenous growth models argue for more permanent effects. The importance attached to investment by these theories has led to an enormous amount of empirical studies examining the relationship between investment and economic growth (Petrakos et al., 2007).

For export-led growth, the theoretical argument goes as follows: The increased demand for exports creates incentives for specialization in the export sector, scale economies and reallocation of resources from the less efficient non-trade sector to the efficient export trade sector, which ultimately increases productivity and output growth. In particular, it has been argued that higher exports enhance access to advanced technologies, skill improvement, learning by doing, management techniques and entrepreneurial activity (Ben-David and Loewy, 1998; Hart, 1983; Lal and Rajapatirana, 1987).

There are four theories to justify the export-led growth hypothesis. First following short-run Keynesian arguments, export growth leads to income growth via the foreign trade multiplier. Second, foreign exchange from exports can be used to finance imported manufactured and capital goods and technology, which contribute to growth. Third, competition leads to scale economies, technological progress and growth. Fourth, the export sector creates positive externalities, such as more efficient management and production techniques, which lead to growth. In contrast, technology trade theory predicts the reverse causality: When domestic demand lags income growth and technological progress results in output increasing faster than domestic demand, exports increase. Conversely, economic growth may reduce export growth when an increase in domestic demand is concentrated in exportable and non-tradable goods so that economic growth increases but exports fall. Finally, intra-industry trade theory predicts feedback: Export-led growth arises when scale economies increase productivity and exports and economic growth leads to export growth when the new market structure has fewer firms and scale economies lead to cost reductions (Dawson, 2006; Reppas and Christopoulos, 2005).

The obtained results of various studies are classified into three parts: In some of them there is a positive relation between the export instability and economic growth but in some other studies the negative correlation has been resulted while in other studies we observe no distinguished relation between tow mentioned parameters.

Some researchers such as MacBean (1966) and Knudsen and Parnes (1975) who confirm that export 
instability may encourage growth, express to suppose a risk-averse behavior, the uncertainty related exports causes to decrease of use and following that increasing the saving investment also finally increasing the economic growth. The very high export instability always constrained the capacity of LDCs to plan and to make the investment programmes through its impact on domestic saving, tax revenue and above all, their capacity to imports. According to MacBean (1966) the export fluctuations may affect not only the peasants who produce exports crops but also the entrepreneurs who undertake investments in the production of manufactured goods (Ozler and Harrigan, 1988).

Knudsen and Parnes (1975) by using the cross section data (mean average of data 1958-68) for 28 developing countries and applying the transitory index to measure of instability found that the marginal propensity of consume obtained from the permanent income has a negative relation to the export instability (Sinha, 1999). Knudsen and Parnes (1975) distinguish between export instability and domestic instability that defined as the instability of GNP less export (Ozler and Harrigan, 1988).

Yotopoulos and Nugent (1976) used two measures of export instability: The squared deviations from an exponential trend index and an index in the spirit of permanent income hypothesis (a transitory index) in their study. The cross section results for 38 developing countries along with the application of second way to evaluate the export instability show decreasing the marginal propensity to consume gained from permanent income follow the uncertainty effect. Also follow that we have increasing at saving and ascending economic growth. In the other hand using the traditional method to measure the export instability leads to the reverse result on which the export instability has a negative effect on economic growth (Sinha, 1999).

In researches Glezakos (1973); Voivodas (1974) and Ozler and Harrigan (1988) there has been regressed the GDP growth rate on the export instability using the obtained results there has been confirmed the negative correlation between the export instability and economic growth. Ozler and Harrigan (1988) employing a model of autoregressive conditional heteroscedasticity to capture the instability index that varies over the 196382 period and 26 developing countries. Also they find that country differences are demonstrated to be important for the magnitude of the export instability impact.

Gyimah-Brempong (1991) in their study for 34 African countries resulted through the average data of (1960-86) also via using the production function framework that the type of measurement the export instability has no effect on study procedure because in any way this variable put a negative effect on economic growth. They used three different ways to measure the export instability as following: (a) The coefficient of variation of export earnings, (b) the mean of the absolute difference between actual export earnings and its trend value, normalized around the trend value of export earnings and (c) average of the squares of the ratio of actual export earnings to trend earnings (Gyimah-Brempong, 1991).

Mullor-Sebastian (1988) uses a different approach to studying the relationship between export instability and economic growth. She argues that studies, which lump exports of all goods, are misleading because export instability of a given product is influenced by the characteristics of the individual product and the degree of development of the exporting 6 countries. Thus, export instability of a particular product will vary depending upon whether the country is a developed country or a developing country. Thus, she confines her study to synthetic fiber (a) growth product) and natural fiber (a) mature product) exports. She finds that export instability of synthetic fiber is higher for the LDCs than for the DCs. However, there are no significant differences between the LDCs when it comes to the natural fiber (Mullor-Sebastian, 1988).

The Love (1992) study is from the initial studies taking the causality relationship between the export instability and income instability by using the time series analysis. The applied proxy to instability was the absolute deviations from a five-year moving average. The obtained results showed to make the income instability following the export instability for all 20 countries.

Another study deals with the relation of economic growth and export stability by time series analysis and unit root test for 9 Asian countries is Sinha (1999) research in 1999 which the most important key results is to take the mistake whereas the using of cross section data to analyze the mentioned correlation also says it is not possible to take the confident expression refer to the relation between tow variables.

The study of Gyimah-Brempong (1991) used neoclassical growth equation to investigate the relationship between export instability and economic growth for 34 sub-Saharan African countries during the 1960-86 period. The results show that export instability has a negative and significant effect on economic growth of these set of countries. Additionally, this negative effect does not depend on the measure of export instability that used. 
The export instability is one reason for benefits of export diversification, which is analogous to the portfolio effect in finance. Commodity products are often affecting from volatile market price, therefore the countries that dependent on these products may suffer from this export instability that generated by very volatile market prices. This could discourage necessary investment in the economy, because this leads to increase macroeconomic uncertainty and in final, it is harmful for long run economic growth (Ghosh and Ostry, 1994; Bleaney and Greenaway, 2001).

Al-Marhubi (2000) in his study used a conventional cross sectional country growth regression that included various measure of export concentration to different model specification. He finds that export diversification promote economic growth. Also, Herzer and Felicitas Nowak-Lehmann (2006) suggest that there is benefit in diversifying of export.

\section{MATERIALS AND METHODS}

Data and methodology: In this study, we survey export instability in a neoclassical production function in the tradition of (Feder, 1983). A number of studies have since followed (Feder, 1983) in study the relationship between export and economic growth in which GDP of a country is made a function of the growth rates of different inputs such as labor, capital and export. We augment this production function by adding a measure of export instability. We follow (Love, 1992) and use the absolute value of the deviations of actual export from a five-year moving average of export.

The entered variables in model are: GDP that is defined as real GDP, EXP is real exports of goods and services; INS is the absolute value of the deviations of export from its five year moving average. This is used as the measure of export instability. Also, to allow for cross-country variation in the effect of instability, this variable interacted with the real export to real GDP ratio. This measure allows us to survey the effect of instability to vary according to the degree of openness of the country. CAP is real gross fixed capital formation (a measure of investment) and POP is total labor force. For using the benefits of linear logarithmic models that they show elasticity with obtained coefficients, all of variables have been used as logarithmic.

In this study we use the panel unit root test proposed by Breitung (2000). The reason for use this panel unit root test is that a recent large-scale Monte Carlo simulation study by Hlouskova and Wagner (2006) found that the Breitung panel unit root test generally had the highest power and smallest size distortion of any of the so called first generation panel unit root tests.
If the model contain a panel unit root the issue arises whether there exists a long run equilibrium relationship between the variables. We test for panel Co-integration by using Kao test (Engle-Granger based), method (Kao and Chiang, 2000).

Empirical results: According to Table 1, the results of Breitung panel unit root test suggest that there are panel unit root variables in model.

Therefore we use of Kao cointegration test to test whether there is a long-run relationship between variables or not. The result of co-integration test shows that there is long-run relation between variables. These are showed in Table 2.

We assume a Cobb-Douglus form of the neoclassical growth model. Export instability may affect the growth process through a direct impact on investment levels or through the efficiency of the already existing capital stock. Also, Export can affect the growth process through direct impact on growth or through the efficiency of the already existing capital stock.

Therefore the estimated model is:

$$
\begin{aligned}
\ln \mathrm{GDP}_{\mathrm{it}}= & \alpha+\beta_{\mathrm{i} 1} \ln \mathrm{POP}_{\mathrm{it}}+\beta_{\mathrm{i} 2} \ln \mathrm{CAP}_{\mathrm{it}}+ \\
& \beta_{3} \ln \mathrm{EXP}_{\mathrm{it}}+\beta_{\mathrm{i} 4} \ln \mathrm{INS}_{\mathrm{it}}+\varepsilon_{\mathrm{it}}
\end{aligned}
$$

Those variables are presented in data and methodology part.

Table 1: Breitung unit root test

\begin{tabular}{lll}
\hline Null hypothesis: Unit root & T-statistic & Probability \\
\hline $\ln$ GDP & -0.07261 & 0.4711 \\
$\ln$ CAP & 0.50267 & 0.6924 \\
$\ln$ POP & 1.59331 & 0.9445 \\
$\ln$ IXP & 0.04870 & 0.5194 \\
$\ln I N S$ & -3.55786 & $0.0002^{*}$ \\
D(lnGDP) & -5.03562 & $0.0000^{*}$ \\
D(lnCAP) & -6.25063 & $0.0000^{*}$ \\
D(lnPOP) & -3.35047 & $0.0004^{*}$ \\
D(lnEXP) & -6.78151 & $0.0000^{*}$ \\
\hline
\end{tabular}

*: Null hypothesis rejected at 5\% significant level

Table 2: Kao residual co-integration test

\begin{tabular}{lll}
\hline Null hypothesis: No co-integration & T-statistic & Probability \\
\hline ADF & -8.049261 & $0.0000^{*}$
\end{tabular}

*: Null hypothesis rejected at $5 \%$ significant level

Table 3: Estimate of random effect model

\begin{tabular}{lccl}
\hline Variable & Coefficient & T-statistic & Probability \\
\hline C & 4.934559 & 4.892461 & $0.0000^{*}$ \\
$\operatorname{lnCAP}$ & 0.227127 & 2.209806 & $0.0277^{*}$ \\
$\ln \mathrm{POP}$ & 0.225159 & 5.608301 & $0.0000^{*}$ \\
$\operatorname{lnEXP}$ & 0.501868 & 5.949847 & $0.0000^{*}$ \\
lnINS & -0.010362 & -3.082892 & $0.0022^{*}$ \\
$\mathrm{R}^{2}: 0.89$ & & \\
F-statistic: 779.9268 & & \\
*: Null hypothesis rejected at 5\% significant level &
\end{tabular}


Selected method for estimated model is Random Effect because, the result of Husman test suggest that random effect is suitable for this model (Table 3).

\section{RESULTS AND DISCUSSION}

The estimated coefficients show that export instability that is peroxide by absolute value of the deviations of export from its five year moving average interacted by trade openness has a significant and low negative effect on growth of this set of East Asia and Pacific countries. A 1\% increase in Export instability leads to approximately $0.01 \%$ decrease in economic growth of these countries. We can see that the export instability is harmful for economic growth because, in these countries risk averse private inventors are likely to reduce the investment or we can say that ex-post efficiency of the existing investment is likely to be reduced. These countries should diversify their exports, this can help them to overcome export instability and in consequence reduce the negative effect of terms of trade in primary products. Thus, export diversification policy can play an important role in decrease of negative effect of export instability on growth of selected countries. Therefore, export diversification policy has two impacts on growth. The indirect impact is reducing of harmful effect of export instability on growth and the direct effect is positive effect of export diversification on growth.

The labor force variable is positive and significant statistical effects on economic growth of selected countries. This result shows that the number of labor force is an important factor for growth in these countries. A $1 \%$ increase in labor force leads to $0.22 \%$ increase in GDP of this set of countries, therefore we can obtain that in these countries number of labor force is important factor for growth of these countries.

The coefficients of gross fixed capital show that a $1 \%$ increase in it leads to $0.22 \%$ increase in GDP of these countries. Also, the effect of export on economic growth in these countries is positive and $1 \%$ increase in export of goods and service leads to $0.50 \%$ increase in GDP of selected countries. Therefore, the increase in export of goods and service can help to drive the growth of these countries.

\section{CONCLUSION}

This study use panel co-integration techniques to examine the existence of long-run relationship between investment, interaction of trade openness and export instability and economic growth in 22 East Asia and Pacific countries. Panel co-integration test shows that the variables of interest put in model (1) are co-integrate.
The results indicate that export has greater impact rather than other factors on economic growth in set of countries. We can gather from the study that labor force has important factor in economic growth of selected countries.

According to result, the impact of export instability on economic growth is negative. Therefore export instability is harmful for economic growth of these set of countries. Because, in these countries risk averse private inventors are likely to reduce the investment or we can say that ex-post efficiency of the existing investment is likely to be reduced. Thus, the policy of export stability must be to attend in decision of policy makers in these countries. These countries should diversify their exports, this can help them to reduce the negative effect of terms of trade in primary products. Therefore, export diversification policy can help to stabilize export earning in the long run. In final, the effect of export and investment on economic growth is positive in these set of countries and supported the theoretically expectations and increase in domestic investment and export of goods and service leads to more economic growth of these set of countries.

\section{REFERENCES}

Al-Marhubi, F., 2000. Export Diversification and Growth: An empirical investigation. Applied Econ. Lett., $\quad 7$ : 559-562. DOI: 10.1080/13504850050059005

Ben-David, D. and M.B. Loewy, 1998. Free-trade, growth and convergence. J. Econ. Growth, 3: 143-170. http://www.ingentaconnect.com/content/klu/joeg/1 998/00000003/00000002/00167017

Bleaney, M. and D. Greenaway, 2001. The impact of terms of trade and real exchange volatility on investment and growth in sub-Saharan Africa. J. Dev. Econ., 65: 491-500.

Breitung, J., 2000. The Local power of some unit root tests for panel data. Adv. Econ., 15:161-177. DOI: 10.1016/s0731-9053(00)15006-6

Dawson, P.J., 2006. The export-income relationship and trade liberalization in Bangladesh. J. Policy Model., 28: 889-896. http://www.sciencedirect.com/science/article/B6V8 2 ... 199ca619ba2726dc390f

Feder, G., 1983. On exports and economic growth. J. Dev. Econ., 12: 59-73. DOI: 10.1016/03043878(83)90031-7

Ghosh, A.R. and J. Ostry, 1994. Export instability and the external balance in developing countries. IMF Staff Papers, 41: 214-35. http://www.jstor.org/stable/3867507 
Giles, J. and C. Williams, 2000. Export-led growth: A survey of the empirical literature and some noncausality results. J. Int. Trade Econ. Dev., 9: 261-267. http://web.uvic.ca/econ/research/papers/ewp0002.p df

Glezakos, C., 1973. Export instability and economic growth: A statistical verification. Econ. Dev. Cult. Change, 21: 670-78. http://www.jstor.org/stable/1152696

Gyimah-Brempong, K., 1991. Export instability and economic growth in sub-Saharan Africa. Econ. Dev. Cult. Change, 39: 815-28. http://www.jstor.org/stable/1154596

Hart, O., 1983. The market mechanism as an incentive scheme. Bell J. Econ., 14: 366-382. http://links.jstor.org/sici?sici=036115X\%28198323\%2914\%3A2\%3C366\%3ATMMA $\mathrm{AI} \% 3 \mathrm{E} 2.0 . \mathrm{CO} \% 3 \mathrm{~B} 2-2 \&$ origin=repec

Herzer, D. and D. Felicitas Nowak-Lehmann, 2006. What does export diversification do for growth? an econometric analysis. Applied Econ., 38: 1825-1838. DOI: $10.1080 / 00036840500426983$

Hlouskova, J. and M. Wagner, 2006. The performance of panel unit and stationary tests: Results from a large scale simulation study. Econ. Rev., 25: 85-116. DOI: 10.1080/07474930500545504

Kao, C. and M.H. Chiang, 2000. On the estimation and inference of a co-integrated regression in panel data. Adv. Econ., 15: 179-222. DOI: 10.1016/s0731-9053(00)15007-8

Kugler, P., 1991. Growth exports and cointegration: An empirical investigation. Weltwirtschaftliches Arch., 127: 73-82. DOI: 10.1007/BF02707311

Knudsen, O. and A. Parnes, 1975. Trade Instability and Economic Development: An Empirical Study. Lexington, Books, London, DC., ISBN: 0669983276, pp: 142.

Lal, D. and S. Rajapatirana, 1987. Foreign trade regime and economic growth in developing countries. World Bank Reserve Observer, 2: 189-217. http://wbro.oxfordjournals.org/cgi/reprint/2/2/189

Love, J., 1992. Export instability and the domestic economy: Questions of causality. J. Dev. Stud., 28: 735-742. DOI: 10.1080/00220389208422256

Lucas, R., 1988. On the mechanics of economic development. J. Monet. Econ., 22: 3-42.

MacBean, A.I., 1966. Export Instability and Economic Development. Harvard University Press, Cambridge, Mass, pp: 367.
Mullor-Sebastian, A., 1988. A new approach to the relationship between export instability and economic development. Econ. Dev. Cult. Change, 36: 217-236. DOI: 10.1086/451649

Mullor-Sebastian, A., 1990. Export instability and policy implication for developing countries as residual suppliers. IMF Working Paper, pp: 1-16. http://ssrn.com/abstract $=884784$

Ozler, S. and J. Harrigan, 1988. Export instability and growth. University of California, Department of Economics Working Paper. No. 486, Los Angeles, pp: $1-28$.

http://www.econ.ucla.edu/workingpapers/wp486.p df

Petrakos, G., P. Arvanitidis and S. Pavleas, 2007. Determinants of economic growth: The experts' view. Working Paper, 1-37. http://www.esri.ie/research/research_areas/internati onal_economics/dynreg/papers/Working_Paper_N o._20.pdf

Reppas, P.A. and D.K. Christopoulos, 2005. The export-output growth nexus: Evidence from African and Asian countries. J. Policy Model., 27: 929-940. DOI: 10.1016/J.JPOLMOD.2005.06.007

Romer, P., 1986. Increasing returns and long run growth. J. Politic. Econ., 94: 1002-1037.

Sinha, D., 1999. Export instability, investment and economic growth in Asian countries: A time series analysis. Yale University, Center Discussion Paper No. 799, pp: 1-23. http://www.econ.yale.edu/growth_pdf/cdp799.pdf

Voivodas, C.S., 1974. The effect of foreign exchange instability on economic growth. Rev. Econ. Stat., 56: 410-412. http://www.jstor.org/pss/1923987

Yaghmaian, B., 1994. An empirical investigation of exports development and growth in developing countries: Challenging the neoclassical theory of export-led growth. World Dev., 22: 1977-1995. DOI: $10.1016 / 0305-750 X(94) 90187-2$

Yotopoulos, P.A. and J.B. Nugent, 1976. In defense of a test of the linkage hypothesis. Q. J. Econ., 90: 334-343. http://www.jstor.org/pss/1884636 